\title{
Minat Jalur Karir Akuntansi dari Perspektif Motivasi Intrinsik, Ekstrinsik, Orang Ketiga dan Eksposur Karir
}

\author{
Hendra Gunawan ${ }^{1 *}$, Atiqotun Nisa ${ }^{2}$, Yuli Afrina ${ }^{3}$ \\ 1, 2, 3 Politeknik Negeri Batam

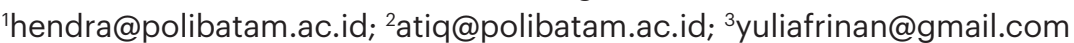 \\ ${ }^{*}$ Penulis korespondensi
}

\begin{abstract}
This study investigates the factors that influence students in choosing a career path in accounting. The decision to choose a career path needs to be detected early because it has an impact on future professional performance which determines both the individual's social position, style and standard of living, and life satisfaction. This study examines the factors that influence the career paths of accounting students through the social cognitive career theory. Based on this theory, the relationship between career path and driving factors such as intrinsic motivation, extrinsic motivation, third party influence, career exposure, is identified. The online survey was conducted on 333 respondents. Through regression analysis, this study found that intrinsic motivation, extrinsic motivation and career exposure have a positive effect while third parties influences do not have a significant value on career paths. These findings could be useful for policy makers and higher education institutions to provide a more supportive environment that will foster interest among accounting students to be motivated in choosing career paths in accounting.
\end{abstract}

Keywords: intrinsic motivation, extrinsic motivation, third parties influence, career exposure, career path

\begin{abstract}
Abstrak
Penelitian ini menyelidiki faktor-faktor yang mempengaruhi mahasiswa dalam memilih jalur karir di bidang akuntansi. Keputusan pemilihan jalur karir tersebut perlu dideteksi secara dini karena berdampak pada kinerja profesi masa depan yang menentukan baik posisi sosial individu, gaya dan standar hidup, serta kepuasan hidup. Penelitian ini mempelajari faktor-faktor yang mempengaruhi jenjang karir mahasiswa akuntansi melalui pendekatan social cognitive career theory. Berdasarkan teori tersebut, hubungan antara jalur karir dengan faktor pendorong seperti motivasi intrinsik, motivasi ekstrinsik, pengaruh pihak ketiga, eksposur karir, diidentifikasi. Survei secara daring dilakukan pada 333 responden. Melalui analisis regresi, penelitian ini menemukan bahwa motivasi intrinsik, motivasi ekstrinsik dan eksposure karir memiliki pengaruh positif sedangkan pengaruh pihak ketiga tidak memiliki nilai signifikan terhadap jalur karir. Temuan ini dapat bermanfaat bagi pembuat kebijakan dan institusi pendidikan tinggi untuk menyediakan lingkungan yang lebih mendukung yang akan menumbuhkan minat di kalangan mahasiswa akuntansi agar termotivasi dalam memilih jalur karir di bidang akuntansi.
\end{abstract}

Kata Kunci: motivasi intrinsik, motivasi ekstrinsik, pengaruh pihak ketiga, eksposur karir, jalur karir 


\section{PENDAHULUAN}

Keputusan memilih jurusan kuliah saat akan memasuki perguruan tinggi adalah salah satu hal terpenting yang dibuat oleh siswa lulusan sekolah menengah atas. Keputusan tersebut berdampak pada kinerja profesi masa depan yang menentukan baik posisi sosial individu, gaya dan standar hidup, serta kepuasan hidup. Efek dari pilihan studi menjangkau jauh ke masa depan memungkinkan realisasi tujuan hidup seseorang, keinginan dan impiannya. Terlebih lagi, keputusan yang salah mengenai pilihan profesi dapat memicu dampak negatif psikologis dan sosial yang dirasakan tidak hanya oleh mereka sendiri, tetapi juga oleh lingkungan terdekat dan juga pemberi kerja. Untuk alasan ini, para siswa lulusan sekolah menengah atas harus membuat keputusan dalam pengambilan jurusan yang ingin mereka pilih secara baik dan bijaksana. Artinya, kaum muda perlu mempertimbangkan minat, kecenderungan dan kebutuhan mereka, serta kompetensi dan keterampilan yang diharapkan oleh pemberi kerja. Dengan cara ini, kegiatan profesional masa depan akan memberikan kepuasan yang sangat besar, tidak menjadi sumber frustrasi dan mengecewakan.

Meskipun demikian, mereka yang memilih jurusan yang berkaitan dengan akuntansi dan keuangan sering mempertimbangkan faktor keuangan dan peluang kerja. Faktor utama yang mempengaruhi pilihan bidang akuntansi oleh mahasiswa di perguruan tinggi diantaranya adalah peluang kerja yang bagus, minat mereka di lapangan (Grace \& Jenkins, 2005) dan potensi penghasilan yang tinggi (Gunawan \& Gunawan, 2019). Penelitian serupa yang menunjukkan pentingnya faktor ekstrinsik yang terkait dengan kemajuan karir, remunerasi dan keamanan kerja juga dilakukan oleh Felton et al. (1994), Jackling \& Keneley (2009), Demagalhaes et al. (2011) serta oleh van Zyl \& de Villiers (2011). Terlepas dari faktorfaktor tersebut, terdapat penelitian lain yang menganalisis pengaruh motivasi intrinsik mahasiswa terhadap pilihan jalur pendidikan dan pekerjaan. Menurut Ryan \& Deci (2000), mahasiswa memilih bidang studi tertentu karena mereka yakin bahwa di masa depan ada kemungkinan untuk mengejar profesi yang memuaskan.

Sejak akhir abad kedua puluh, cukup banyak penelitian mengenai faktor-faktor yang mempengaruhi pilihan pendidikan dan profesional oleh mahasiswa. Mereka melibatkan orang-orang yang mempelajari berbagai bidang ilmu yang ditawarkan oleh perguruan tinggi, seperti bidang keuangan dan akuntansi, sosiologi, pedagogi, manajemen, filologi bahasa Inggris, ilmu komputer dan matematika. Penelitian yang dilakukan oleh Sugahara \& Boland (2006) menunjukkan bahwa alasan utama untuk memilih bidang tertentu adalah dari minat mahasiswa sendiri. Selanjutnya responden memperhitungkan kemungkinan mendapatkan pekerjaan setelah lulus dari perguruan tinggi. Minat mahasiswa sendiri juga merupakan faktor yang berpengaruh besar terhadap pemilihan jurusan di pihak masyarakat yang pada saat penelitian sedang menempuh pendidikan di perguruan tinggi dengan program akuntansi yang terakreditasi. Hal ini diperkuat oleh hasil penelitian yang diperoleh Sugahara \& Boland (2006) serta oleh Muhamad et al. (2016).

Jenjang karir dapat digambarkan sebagai perencanaan hidup jangka panjang individu di mana rencana tersebut dimulai ketika seseorang memasuki pasar kerja (Yusoff et al. 2011). Penelitian tentang jalur karir bidang akuntansi mempertimbangkan berbagai faktor 
seperti motivasi intrinsik, motivasi ekstrinsik, pengaruh pihak ketiga, eksposur karir dan persepsi ( $\mathrm{Ng}$ et al. 2017; Dibabe et al. 2015). Memahami jalur karir adalah bagian penting dari pendewasaan dan sangat penting untuk mencapai kesuksesan. Oleh karena itu, penelitian ini menguji persepsi karir melalui faktor-faktor yang mencerminkan pilihan bidang akuntansi tersebut. Social cognitive career theory (SCCT) yang dikembangkan oleh Lent et al. (1994) membahas proses pengembangan karir berdasarkan social cognitive theory (SCT) yang dikemukakan oleh Bandura (1986). SCCT menyatakan bahwa unsur-unsur yang mempengaruhi proses pengambilan keputusan karir seseorang adalah perilaku dan lingkungannya (Zotorvie, 2016). Leung et al. (2008) mengusulkan tiga model segmental untuk menjelaskan pendidikan dan pilihan karir, dan pendidikan dan kinerja karir. Model berpusat di sekitar tiga variabel, yaitu, efisiensi diri, ekspektasi hasil dan tujuan pribadi.

Pada dasarnya mahasiswa akuntansi memiliki banyak pilihan dalam hal peningkatan karir setelah lulus. Misalnya, mereka dapat memilih karir di bidang akuntansi keuangan, perpajakan, akuntansi manajemen, audit, keuangan, dan sebagainya. Perubahan pilihan yang menarik yang terjadi di dunia kerja dapat saja berubah setiap saat terlebih dengan kemudahan mendapatkan informasi melalui bantuan teknologi informasi yang semakin berkembang (Gunawan, 2012). Akibat dari perubahan dinamis yang terjadi di dunia kerja tersebut, informasi mengenai pilihan posisi karir tersebut menjadi penting karena memungkinkan munculnya adaptasi pendidikan yang ditawarkan oleh perguruan tinggi. Penelitian ini bertujuan untuk mengetahui sejauh mana pengaruh motivasi intrinsik, motivasi ekstrinsik, pengaruh pihak ketiga, dan eksposur karir terhadap jalur karir mahasiswa akuntansi. Hasil dari penelitian ini diharapkan dapat memberikan manfaat bagi perguruan tinggi untuk mengidentifikasi dan membantu mahasiswa dalam memutuskan pilihan karirnya. Perguruan tinggi dapat memberikan tawaran adaptasi model pendidikan yang lebih berani baik dengan penyesuaian kurikulum maupun perombakan metode pengajaran yang lebih mudah mempertemukan harapan mahasiswa dengan dunia kerjanya. Selain itu, perguruan tinggi dapat berperan aktif menyampaikan gambaran dunia kerja lebih awal sebagai bagian dari salah satu faktor penyumbang bagi mahasiswa dalam memilih jalur karirnya.

Penelitian ini mengembangkan penelitian yang pernah dilakukan oleh beberapa peneliti sebelumnya seperti Demagalhaes, Wilde\& Fitzgerald (2011), Dibabe, Wubie \& Wondmagegn (2015), serta oleh Muhamad et al. (2016). Namun penelitian ini memiliki perbedaan karena menggunakan pendekatan SCCT yang dikembangkan oleh Lent et al. (1994). Pendekatan tersebut membahas proses pengembangan karir berdasarkan SCT yang dikemukakan oleh Bandura (1986).

\section{METODE}

\section{Populasi dan Sampel}

Survei kuesioner dalam bentuk survei cross-sectional dilakukan untuk mengumpulkan data. Data yang dikumpulkan dari survei adalah data primer. Populasi penelitian ini adalah mahasiswa D3 Akuntansi dan D4 Akuntansi Manajerial di Politeknik Negeri Batam. Penelitian ini menerapkan strategi pengumpulan data menggunakan sampel dari populasi karena 
banyaknya jumlah mahasiswa akuntansi yang terdaftar di Politeknik Negeri Batam. Strategi tersebut untuk menghindari ketidakpraktisan mengumpulkan dan menganalisis semua data mengingat keterbatasan waktu dan sumber daya di masa pandemi Covid-19. Metode convenience bagi responden digunakan dalam penelitian ini sehingga responden dapat ikut berkontribusi atau menolak mengisi kuesioner. Kuesioner disebarkan menggunakan media daring Google Form yang tautannya disebarkan kepada responden melalui grup percakapan Whatsapp sehingga kuesioner dapat dengan mudah diakses dan responden secara sukarela menanggapi. Sebanyak 333 responden mengisi kuesioner yang disebarkan.

\section{Instrumen Penelitian}

Kuesioner penelitian terdiri dari enam bagian yang merujuk pada penelitian $\mathrm{Ng}$ et al. (2017). Fokus utamanya adalah pada perencanaan karir di bidang akuntansi setelah lulus. Seperti penelitian sebelumnya, variabel ini diukur dengan skala likert lima poin mulai dari 1 sampai 5 (sangat tidak setuju sampai sangat setuju). Bagian pertama ditujukan untuk mengumpulkan profil demografis responden. Item pertanyaan di bagian kedua berisi lima pertanyaan yang berkaitan dengan variabel intrinsik. Motivasi ekstrinsik pada bagian ketiga berisi lima item pertanyaan. Bagian keempat terdiri dari lima item pertanyaan untuk variabel pengaruh orang ketiga. Eksposur karir dinilai pada bagian kelima melalui lima pertanyaan. Variabel dependen jalur karir dinilai dengan lima pertanyaan pada bagian keenam.

\section{Teknik Analisis Data}

Analisis deskriptif digunakan terlebih dahulu untuk mengetahui karakteristik atau profil demografis responden. Uji normalitas digunakan untuk menguji apakah nilai residual terdistribusi melalui uji Kolmogorov Smirnov. Kriteria pengambilan keputusannya >0,05 untuk data berdistribusi normal. Uji multikolinearitas dipakai untuk memastikan ditemukan adanya korelasi yang tinggi antar variabel independen dengan nilai toleransi $>0,10$ dan nilai $\mathrm{VIF}<10$. Kemudian uji heteroskedastisitas digunakan untuk menguji apakah model regresi terjadi ketidaksamaan variance dari satu pengamatan ke pengamatan lain dengan acuan nilai signifikan $>0,05$.

Teknik analisis pada penelitian ini menggunakan uji t dengan tujuan untuk mengetahui seberapa jauh pengaruh variabel motivasi intrinsik, motivasi ekstrinsik, pengaruh pihak ketiga, dan eksposur karir secara individual dalam menerangkan variasi variabel dependennya yaitu pilihan jalur karir. Pengujian dilakukan dengan menggunakan signifikansi $\alpha=5 \%$. Terakhir koefisien determinasi digunakan untuk menilai seberapa jauh kemampuan variasi variabel dependen dalam model regresi.

\section{HASIL DAN PEMBAHASAN}

\section{Statistik Deskriptif}

Karakteristik responden dalam penelitian ini menjelaskan profil responden dalam pemilihan jalur karir sebanyak 333 mahasiswa D3 Akuntansi dan D4 Akuntansi Manajerial di Politeknik Negeri Batam. Komposisi responden terdiri dari 44\% mahasiswa D3 Akuntansi 
dan 56\% mahasiswa D4 Akuntansi Manajerial. Responden yang terdaftar di semester 1 sebanyak 66\% mendominasi sampel dibandingkan dengan akumulasi sampel lainnya. Selain itu mayoritas sampel juga berasal dari lulusan non eksakta sebanyak 63\%. Dilihat dari sisi gender, perempuan mendominasi jumlah responden dan dari segi umur, 64\% berumur 17-19 tahun. Hal ini wajar mengingat sampel lebih banyak yang terdaftar di semester 1. Data selengkapnya mengenai karakteristik responden dapat dilihat pada Tabel 1.

Tabel 1 Karakteristik Responden

\begin{tabular}{|c|c|c|}
\hline n: 333 & $\mathbf{q}$ & $\%$ \\
\hline \multicolumn{3}{|l|}{ Prodi } \\
\hline D3 AK & 148 & $44 \%$ \\
\hline D4 AM & 185 & $56 \%$ \\
\hline \multicolumn{3}{|l|}{ Semester } \\
\hline 1 & 219 & $66 \%$ \\
\hline 2 & 39 & $12 \%$ \\
\hline 3 & 14 & $4 \%$ \\
\hline 4 & 5 & $2 \%$ \\
\hline 5 & 10 & $3 \%$ \\
\hline 6 & 17 & $5 \%$ \\
\hline 7 & 5 & $2 \%$ \\
\hline 8 & 24 & $7 \%$ \\
\hline \multicolumn{3}{|l|}{ Asal SMA } \\
\hline Eksakta & 123 & $37 \%$ \\
\hline Non Eksakta & 210 & $63 \%$ \\
\hline \multicolumn{3}{|l|}{ Gender } \\
\hline Perempuan & 284 & $85 \%$ \\
\hline Laki laki & 49 & $15 \%$ \\
\hline \multicolumn{3}{|l|}{ Umur } \\
\hline 17-19 Tahun & 212 & $64 \%$ \\
\hline 20 Tahun & 54 & $16 \%$ \\
\hline 21 Tahun & 36 & $11 \%$ \\
\hline > 22 Tahun & 31 & $9 \%$ \\
\hline
\end{tabular}

Sumber: Data primer diolah, 2020

Berdasarkan pengolahan statistik hasilnya dapat dilihat pada Tabel 2. Sampel dapat dideskripsikan bahwa mean berada dikisaran poin 4 dan hanya variabel ekstrinsik dan pengaruh pihak ketiga yang berada pada poin 3,97 dan 3,23. Hal ini berarti tanggapan responden mengarah lebih condong ke sisi kanan pada peryataan pendapat setuju-sangat setuju. Hal ini dipertegas dengan nilai median yang mengarah ke sisi kanan. Begitupun modus yang menegaskan bahwa respoden lebih banyak memilih poin 4 (setuju) dari keseluruhan item pertanyaan di kuesioner. Meskipun terlihat ada responden yang mengisi poin 1 (sangat tidak setuju) seperti terlihat pada nilai minimal. 
Tabel 2 Statistik Responden

\begin{tabular}{ccccccc}
\hline n: 333 & Min & Max & Mean & Std. Dev. & Median & Modus \\
\hline MI & 1 & 5 & 4,14 & 0,51 & 4 & 4 \\
ME & 1 & 5 & 3,97 & 0,53 & 4 & 4 \\
OK & 1 & 5 & 3,23 & 0,67 & 3,2 & 3,2 \\
EK & 1 & 5 & 4,09 & 0,42 & 4 & 4 \\
JK & 1 & 5 & 4,10 & 0,53 & 4 & 4 \\
\hline
\end{tabular}

Sumber: Data primer diolah, 2020

\section{Pengujian Asumsi Klasik}

Hasil uji normalitas terhadap nilai residual masing-masing variabel menggunakan metode Kolmogrov Smirnov diperoleh nilai sig. (p-value) $=0,963$ yang lebih besar daripada nilai $\alpha=0,05$ maka dapat disimpulkan bahwa semua variabel berdistribusi normal. Pengujian terhadap variabel independen menunjukkan nilai tolerance dari masing-masing variabel $>0,10(0,734 ; 0,631 ; 0,946 ; 0,641)$ dan nilai VIF $<10(1,363 ; 1,584$; multikolinearitas 1,0578; 1,561) sehingga variabel independen bebas dari multikolinearitas. Hasil uji heteroskedasitas diperoleh dengan nilai signifikansi $>0,05(0,751 ; 0,664 ; 0,307 ; 0,086)$ maka dapat disimpulkan model regresi bebas dari heteroskedasitas. Pengujian asumsi klasik dapat dilihat pada Tabel 3.

Tabel 3 Pengujian Asumsi Klasik

\begin{tabular}{|c|c|c|}
\hline$\alpha=0,05$ & & \\
\hline Normalitas & & p-value $=, 963$ \\
\hline Multikolinearitas & Tolerance & VIF \\
\hline MI & ,734 & 1,363 \\
\hline $\mathrm{ME}$ & 631 & 1,584 \\
\hline PK & ,946 & 1,057 \\
\hline EK & 641 & 1,561 \\
\hline Heteroskedasitas & & Sig. \\
\hline MI & & 0,751 \\
\hline ME & & 0,664 \\
\hline PK & & 0,307 \\
\hline EK & & 0,086 \\
\hline
\end{tabular}

Sumber: Data primer diolah, 2020 


\section{Pengujian Hipotesis}

Pengujian masing-masing hipotesis dirangkum dalam Tabel 4 berikut.

Tabel 4 Pengujian Hipotesis

\begin{tabular}{ccccc}
\hline & Konstanta & $\begin{array}{c}\text { Koefisien } \\
\text { Regresi }\end{array}$ & R Square & Sig. \\
\hline MI & 1,396 &, 653 &, 392 &, 000 \\
ME & 1,976 &, 534 &, 280 &, 000 \\
PK & 3,776 &, 100 &, 016 &, 022 \\
EK & 1,474 &, 641 &, 253 &, 000 \\
Anova & & & & \\
Regression & F-value $=77,755$ &, 487 &, 000 \\
\hline \multicolumn{2}{l}{ Dependent Variable: jk } & $\alpha=0,05$ & & \\
\hline
\end{tabular}

Sumber: Data primer diolah, 2020

Hasil pengujian $\mathrm{H} 1$ yang menyatakan bahwa motivasi intrinsik (mi) memiliki pengaruh positif terhadap jalur karir menunjukkan hasil bahwa nilai signifikansi p-value untuk variabel motivasi intrinsik $(0,000)$ lebih kecil daripada nilai probabilitasnya $(0,005)$, sehingga hipotesis pertama dapat diterima. Hasil ini memberikan nilai konstanta 1,396 dan R square 0,392. Sehingga model persamaan regresi yang terbentuk adalah $Y_{j k}=1,396+0,653 m i+e$. Sedangkan kontribusi pengaruh variabel motivasi intrinsik terhadap jalur karir sebesar 0,392. Hasil pengujian $\mathrm{H} 2$ yang menyatakan bahwa motivasi ekstrinsik (me) memiliki pengaruh positif terhadap jalur karir menunjukkan hasil bahwa nilai signifikansi p-value untuk variabel motivasi ekstrinsik $(0,000)$ lebih kecil daripada nilai probabilitasnya $(0,005)$, sehingga hipotesis kedua dapat diterima. Hasil ini memberikan nilai konstanta 1,976 dan R square 0,280. Sehingga model persamaan regresi yang terbentuk adalah $Y_{j k}=1,976+0,534 m e+e$. Sedangkan kontribusi pengaruh variabel motivasi ekstrinsik terhadap jalur karir sebesar 0,280.

Hasil pengujian H3 yang menyatakan bahwa pengaruh orang ketiga (pk) memiliki pengaruh positif terhadap jalur karir menunjukkan hasil bahwa nilai signifikansi p-value untuk variabel pengaruh orang ketiga $(0,022)$ lebih besar daripada nilai probabilitasnya $(0,005)$, sehingga hipotesis ketiga tidak dapat diterima. Hasil pengujian $\mathrm{H} 4$ yang menyatakan bahwa eksposur karir (ek) memiliki pengaruh positif terhadap jalur karir menunjukkan hasil bahwa nilai signifikansi p-value untuk variabel eksposur karir $(0,000)$ lebih kecil daripada nilai probabilitasnya $(0,005)$, sehingga hipotesis keempat dapat diterima. Hasil ini memberikan nilai konstanta 1,474 dan $\mathrm{R}$ square 0,253 . Sehingga model persamaan regresi yang terbentuk adalah $Y_{j k}=1,474+0,641 e k+e$. Sedangkan kontribusi pengaruh variabel motivasi ekstrinsik terhadap jalur karir sebesar 0,253.

Koefisien determinasi menunjukkan bahwa hanya 48,7\% dari jalur karir yang dijelaskan oleh variasi variabel independen (motivasi intrinsik, motivasi ekstrinsik, pengaruh pihak ketiga, eksposur karir), sedangkan 51,3\% variabel dependen sisanya dijelaskan oleh variabel 
lain. Selanjutnya, model dianggap signifikan karena p-value kurang dari alpha 0,05 dengan nilai $\mathrm{F}$ statistik 77,755 yang tergolong tinggi. Secara umum model sudah dapat dianggap cukup fit. Selanjutnya, persamaan model regresi penelitian ini menjelaskan hubungan antara variabel dependen dan independen. Persamaan lengkap yang diuji adalah sebagai berikut dengan asumsi mengesampingkan variabel pengaruh orang ketiga:

$$
\mathrm{Y}_{\mathrm{jk}}=0,348+0,460 \mathrm{mi}+0,229 \mathrm{me}-0,004 \mathrm{pk}+0,232 \mathrm{ek}+\mathrm{e}
$$

\section{Analisis Data}

Penelitian ini menemukan bahwa motivasi intrinsik memiliki pengaruh positif yang signifikan terhadap jenjang karir. Hasil ini konsisten dengan banyak penelitian sebelumnya seperti Ng et al. (2017), Hsiao \& Nova (2016), Mbawuni \& Nimako (2015), dan Odia \& Ogiedu (2013) yang juga menemukan pengaruh yang signifikan antara kedua variabel tersebut. Dengan demikian, motivasi intrinsik dapat dianggap sebagai salah satu faktor terpenting yang mempengaruhi jalur karir mahasiswa akuntansi (Odia \& Ogiedu, 2013; Mbawuni \& Nimako, 2015, Ng et al. 2017). Berdasarkan hasil tersebut dapat dikatakan bahwa sebagian besar mahasiswa akuntansi memilih jalur karir di bidang akuntansi karena menurut mereka akuntansi itu menarik, dinamis dan menantang selain dari keyakinan mereka sendiri bahwa mereka memiliki kemampuan dalam bidang tersebut seperti dalam melakukan perhitungan. Singkatnya, faktor internal mahasiswa akuntansi seperti minat, keinginan lingkungan atau kondisi tertentu serta kemampuan dan kemampuan akuntansi mempengaruhi jenjang karirnya. Hal ini dikarenakan sebagian besar mahasiswa akuntansi saat ini akan memilih karir di bidang akuntansi jika mereka menyukai akuntansi dan jika mereka merasa dapat mengatasi pekerjaan rumit yang ditugaskan di bidang tersebut. Namun, pekerjaan tersebut harus menantang dan dinamis karena mereka akan lebih bersemangat untuk menyelesaikannya dan tidak akan mudah membuat mereka bosan.

Pengujian untuk hipotesis kedua hasilnya ditemukan bahwa terdapat pengaruh positif yang signifikan antara motivasi ekstrinsik dengan jenjang karir. Hasil ini menunjukkan beberapa kesamaan dengan penelitian yang dilakukan oleh Tang \& Seng (2016); Myburgh (2005); Byrne et al (2012); Porter dan Wolley, (2014) namun berbeda dengan hasil penelitian dari Ng et al. (2017) yang menemukan pengaruh positif yang signifikan antara motivasi ekstrinsik dengan jenjang karir. Alasan utama pengaruh antara motivasi ekstrinsik dan jalur karir adalah karena mahasiswa akuntansi saat ini selain memperhatikan penghargaan dan kepuasan internal juga mengharapkan penghargaan eksternal seperti gaji dan karir dalam pekerjaan. Tidak hanya itu, mahasiswa akuntansi juga memperhitungkan gaji dan tunjangan dalam pengambilan keputusan jenjang karirnya karena mereka mengetahui dengan baik rata-rata gaji lulusan akuntansi yang tergolong di atas rata-rata.

Penelitian ini menemukan bahwa pihak ketiga tidak memiliki pengaruh yang signifikan dengan jalur karir. Temuan ini tidak menghasilkan temuan yang sama dengan studi yang dilakukan oleh Tang \& Seng (2016); Myburgh (2005); Byrne et al (2012); Porter dan Wolley, (2014). Hasil tersebut diyakini karena sebagian besar generasi muda saat ini termasuk mahasiswa akuntansi lebih memilih perbedaan. Mereka memiliki pemikiran dan 
keinginan sendiri tentang apa yang mereka inginkan dan mereka tidak suka terlalu banyak dipengaruhi oleh orang lain dalam pengambilan keputusan seperti dalam menentukan jenjang karir. Hal ini mengindikasikan bahwa banyak mahasiswa akuntansi saat ini perlahan meninggalkan budaya ketergantungan pada orang lain dan tidak berharap mendapatkan pengaruh pihak ketiga dalam menentukan jalur karir mereka. Kebanyakan dari mereka menjadi lebih mandiri dalam menentukan pilihan karir masa depan mereka.

Hipotesis keempat yang melihat pengaruh eksposur karir terhadap jenjang karir hasilnya menunjukkan positif yang signifikan. Temuan ini sesuai dengan penelitian sebelumnya yang dilakukan oleh Ng et al. (2017), Hutaibat (2012), Ghani et al. (2008), dan Sugahara \& Boland (2006) yang menyimpulkan bahwa eksposur karir memiliki pengaruh yang positif dengan jenjang karir. Hasil ini dikarenakan mahasiswa akuntansi mungkin telah menyadari bahwa informasi atau eksposur yang mereka terima memberikan harapan bagi masa depannya. Hal ini dikarenakan biasanya informan berusaha untuk memberikan informasi yang positif tentang karir di bidang akuntansi kepada mahasiswa akuntansi dengan harapan dapat mengikuti bidang tersebut.

Temuan penelitian ini memiliki implikasi ke berbagai pihak yang meliputi perusahaan yang akan merekrut, perguruan tinggi terutama yang memiliki jurusan akuntansi serta badan profesi akuntansi. Pihak-pihak tersebut disarankan untuk memfokuskan pada faktor-faktor yang ditemukan memiliki pengaruh yang signifikan dengan jalur karir. Tidak hanya itu, hasil motivasi intrinsik menunjukkan bahwa perguruan tinggi harus memastikan mahasiswa akuntansi memperoleh pengetahuan dan keterampilan yang cukup di bidang akuntansi selama mereka menempuh pendidikan sehingga mereka akan memilih karir di bidang akuntansi bila mereka yakin memiliki kemampuan untuk menangani tugas-tugas seperti audit dan perpajakan. Selain itu, perusahaan yang akan merekrut juga harus merancang lingkungan yang lebih menantang dan dinamis di tempat kerja sehingga lulusan akuntansi nantinya tertarik untuk bekerja di sana. Terakhir, semua pihak khususnya badan profesi dan perguruan tinggi hendaknya menyelenggarakan kegiatan yang akan membuat mahasiswa akuntansi merasa tertarik dengan bidang akuntansi.

Penelitian ini juga berkontribusi dengan memberikan beberapa penjelasan terkait SCT. SCT mengusulkan keterkaitan antara semua variabel, namun tidak semua faktor dalam penelitian ini ditemukan menjadi prediktor yang signifikan. Penelitian ini memberikan bukti tentang keterkaitan antara motivasi intrinsik, motivasi ekstrinsik, dan eksplosur karir dengan jalur karir untuk memberikan bukti lebih lanjut tentang kekuatan model atau kerangka konseptual SCT. Pertama, penelitian ini membuktikan bahwa faktor perilaku dan pribadi saling berkaitan karena sebagian besar mahasiswa akuntansi yang berminat di bidang akuntansi dan memiliki pengetahuan atau keterampilan (faktor perilaku) di bidang tersebut akan memutuskan untuk bekerja sebagai akuntan (faktor pribadi). Selain itu, penelitian ini secara tidak langsung menunjukkan bahwa ketika seorang mahasiswa akuntansi memiliki minat (faktor perilaku) di bidang akuntansi, maka ia akan lebih rela untuk meningkatkan pengetahuan atau kemampuannya di bidang tersebut dengan belajar lebih giat (faktor pribadi). Tidak hanya itu, dari penelitian ini diketahui bahwa pengaruh yang terlalu besar dari pihak ketiga (faktor lingkungan) tidak mempengaruhi kemungkinan 
memasuki bidang akuntansi (faktor personal) karena mereka lebih merasa ingin berbeda dan mereka menjadi jauh lebih mandiri dalam pengambilan keputusan (faktor perilaku). Singkatnya, hal ini menunjukkan bahwa faktor lingkungan, pribadi dan perilaku saling berkaitan.

\section{SIMPULAN}

Motivasi intrinsik memiliki pengaruh positif terhadap jenjang karir. Hal ini menunjukkan bahwa kepentingan dan kemampuan diri di bidang akuntansi secara langsung mendorong seseorang untuk melanjutkan jenjang karirnya di bidang tersebut. Begitupun motivasi ekstrinsik memiliki pengaruh positif terhadap jenjang karir karena mahasiswa akuntansi meyakini bahwa bidang akuntansi dapat memberikan mereka gaji yang tinggi, kesempatan kerja yang baik dan kemajuan karir yang baik di bidang lain seperti manajemen. Selanjutnya pengaruh pihak ketiga tidak menunjukkan nilai signifikan terhadap jenjang karir. Hal ini dikarenakan mahasiswa akuntansi saat ini tidak ingin ikut-ikutan dan lebih memilih berbeda dengan orang lain. Selain itu mereka memiliki cita-cita dan keinginan sendiri. Mereka tidak suka dipengaruhi oleh orang lain dalam memutuskan apa yang ingin mereka lakukan atau pekerjaan apa yang akan diraih. Terakhir, eksposur karir memiliki pengaruh positif terhadap jenjang karir, hal ini menunjukkan bahwa semakin banyak informasi atau pengetahuan yang dimiliki oleh seorang mahasiswa akuntansi tentang karir di bidang akuntansi maka akan semakin besar kemungkinan mereka akan bekerja di bidang tersebut.

Penelitian empiris sebelumnya yang relevan dengan penelitian ini sebagian besar dilakukan untuk mengevaluasi faktor-faktor seperti motivasi intrinsik, motivasi ekstrinsik, pengaruh pihak ketiga dan eksposur karir. Namun, belum banyak penelitian dengan topik serupa yang mempelajari faktor biaya peluang (opportunity cost) dan niat bekerja di luar negeri. Penelitian berikutnya disarankan untuk dapat memperluas penelitian dengan menambahkan variabel biaya peluang dan niat bekerja di luar negeri. Penelitian yang berkaitan dengan variabel biaya peluang diperlukan guna mempertimbangkan pengorbanan biaya yang harus dikeluarkan untuk memasuki bidang akuntansi. Hal ini dipercaya karena memasuki bidang akuntansi membutuhkan pengorbanan uang dan waktu, seperti untuk mengikuti sertifikasi profesi dan kompetensi. Peluang penelitian berikutnya juga dapat mempertimbangkan variabel niat bekerja di luar negeri untuk melihat respon mahasiswa akuntansi jika mereka ditawari bekerja di luar negeri setelah lulus dengan harapan memperoleh kondisi hidup yang lebih baik. Penelitian tersebut nantinya diharapkan dapat mengidentifikasi apakah faktor ini benar-benar mempengaruhi jalur karir. Selain itu, penelitian selanjutnya dapat mempertimbangkan penelitian pada topik serupa dengan menggunakan metode yang berbeda. Sesi wawancara terstruktur dan mendalam dapat dilakukan untuk mengumpulkan data konkrit yang komprehensif dari responden. Hal ini tidak hanya terkait dengan klarifikasi ambiguitas tetapi juga meningkatkan akurasi data yang dikumpulkan. Ditambah lagi, peneliti juga dapat menemukan relevansi faktor-faktor baru yang belum pernah dipelajari atau diperhatikan oleh peneliti sebelumnya. 


\section{PUSTAKA ACUAN}

Bandura, A. (1986). Social foundations of thought and action: A social cognitive theory. Englewood Cliffs, NJ: Prentice-Hall.

Byrne, M., Willis, P., \& Burke, J. (2012). Influences on school leavers' career decisionsimplications for the accounting profession. The International Journal of Management Education, 10(2), 101-111.

Demagalhaes, R., Wilde, H., \& Fitzgerald, L. R. (2011). Factors affecting accounting students' employment choices: a comparison of students' and practitioners' views. Journal of Higher Education Theory and Practice, 11(2), 32-41.

Dibabe, T. M., Wubie, A. W., \& Wondmagegn, G. A. (2015). Factors that affect students' career choice in accounting: A case of Bahir Dar University students. Research Journal of Finance and Accounting, 6(5), 146-153.

Felton, S., Buhr, N., \& Northey, M. (1994). Factors influencing the business student's choice of a career in chartered accountancy. Issues in Accounting education, 9(1), 131-141.

Ghani, E. G., Said, J., Nasir, N. M., \& Jusoff, K. (2008). The 21st century accounting career from the perspective of the Malaysian University Students. Asian Social Science, 4(8), 73-83.

Grace, E., \& Jenkins, E. (2005). Factors attracting students to accounting: A focus on gender and language. San Jose State University working paper series.

Gunawan, H. (2012). Gender dalam Perspektif Academic Self-Efficacy dan Kecurangan Teknologi Informasi. Jurnal Integrasi, 4(1), 107-110.

Gunawan, M. A., \& Gunawan, H. (2019). Compensation, Competence, Organizational Commitment and Its Effect on Employee Performance: Job Satisfaction as Interverning. Journal of Applied Accounting and Taxation, 4(2), 144-149.

Hsiao, J., \& Nova, S. P. C. C. (2016). Generational approach to factors influencing career choice in accounting. Revista Contabilidade \& Finanças-USP, 27(72), 393-407.

Hutaibat, K. (2012). Interest in the management accounting profession: Accounting students" perceptions in Jordanian Universities. Asian Social Science, 8(3), 303-316.

Jackling, B., \& Keneley, M. (2009). Influences on the supply of accounting graduates in Australia: A focus on international students. Accounting \& Finance, 49(1), 141-159.

Lent, R. W., Brown, S. D., \& Hackett, G. (1994). Toward a unifying social cognitive theory of career and academic interest, choice, and performance. Journal of Vocational Behavior, 45(1), 79-122.

Leung, S. A., Athanasou, J., \& Esbroeck, R. (2008). The big five career theories. International handbook of career guidance.

Mbawuni, J., \& Nimako, S. G. (2015). Modelling job-related and personality predictors of intention to pursue accounting careers among undergraduate students in Ghana. World Journal of Education, 5(1), 65-81.

Muhamad, H., Salleh, M. M., \& Nordin, M. S. M. (2016). Factors influencing career choice 
of accounting students in University Putra Malaysia: Qualitative pilot study. Journal of Advanced Research in Social and Behavioural Sciences, 5(1), 25-34.

Ng, Y. H., Lai, S. P., Su, Z. P., Yap, J. Y., Teoh, H. Q., \& Lee, H. (2017). Factors influencing accounting students' career paths. Journal of Management Development, 36(3).

Odia, J. O., \& Ogiedu K. O. (2013). Factors affecting the study of accounting in Nigerian Universities. Journal of Educational and Social Research, 3(3), 89-96.

Porter, J., \& Woolley, D. (2014).An examination of the factors affecting students' decision to major in accounting. International Journal of Accounting and Taxation, 2(4), 1-22.

Ryan, R. M., \& Deci, E. L. (2000). Intrinsic and extrinsic motivations: Classic definitions and new directions. Contemporary educational psychology, 25(1), 54-67.

Sugahara, S., \& Boland, G. (2006). Perceptions of the certified public accountants by accounting and non-accounting tertiary students in Japan. Asian Review of Accounting, 14(1/2), 149-167.

Tang, L. C., \& Seng, C. (2016). Factors influence students' choice of accounting major in Cambodian universities. Asian Review of Accounting, 24(2), 231-251.

Van Zyl, C., \& de Villiers, C. (2011). Why some students choose to become chartered accountants (and others do not). Meditari Accountancy Research, 19(1/2), 56-74.

Yusoff, Y., Omar, Z. A., Awang, Y., Yusoff, R., \& Jusoff, K. (2011). Does knowledge on professional accounting influence career choice. World Applied Sciences Journal (Special Issue on Bolstering Economic Sustainability), 12, 57-60.

Zotorvie, J. (2016). Determinants of career choice among students of institute of chartered accountants (Ghana). European Scientific Journal, 12(31). 